\title{
Monitoring of the Development Potential of Educational Services in General Secondary Education Institutions
}

\author{
Zvarych Hanna \\ Head deputy of the Department of Education and Science \\ Ternopil Regional State Administration (Ternopil, Ukraine) \\ ORCID https://orcid.org/0000-0002-4120-5729
}

\begin{abstract}
The article considers the results of scientific research on the problem of monitoring the quality of educational services, as well as analyzes and summarizes the important parameters of such monitoring. The activities of educational institution have many components and aspects. Proposed to develop integrated indicators of the quality of educational services, which would combine many factors of educational activities and reflect the central goal of the educational process - the development of the child's personality. The author writes that comprehensive personal development is the main goal of educational activities, so such an integral criteria for the quality of educational services can be the development potential of the educational process in educational institutions. The article considers the system of students' skills, abilities, personal and mental qualities, which provide an opportunity to successfully acquire the necessary school knowledge and skills. They are considered as indicators and manifestations of effective developmental effect of the educational process on the student's personality. They characterize the development potential of educational services. Described the following types of universal learning activities: cognitive (ability to learn, logical thinking, etc.), communicative (social competence, ability to communicate, etc.), regulatory (goal setting, planning, etc.), personal (provide valuesemantic and moral-ethical orientations of students ). Criteria and levels for assessing the development potential of educational services were presented.

Key words: monitoring of quality of educational services, development potential, universal educational actions, cognitive actions, regulatory activity.
\end{abstract}

Постановка проблеми. Питання оцінювання рівню менеджменту освіти, підвищення якості надання освітніх послуг й рівня навчально-виховного процесу в цілому були та залишаються дуже актуальними для сучасної української освітянської науки і практики. Як зазначається в Рекомендаціях до побудови внутрішньої системи забезпечення якості освіти: «Головною метою освітньої діяльності закладу загальної середньої освіти є всебічний розвиток людини як особистості та найвищої цінності суспільства. Досягти даної мети можна, забезпечивши високий рівень якості освіти. Як забезпечити високу якість у закладі освіти, діяльність якого багатокомпонентна i побудована на різних механізмах взаємодії?» [1, с. 2]. Відповідаючи на це питання, ми пропонуємо виробити інтегральні показники якості освітніх послуг, які б об'єднували багато факторів, аспектів, компонентів освітньої діяльності та виводили на центрального суб’єкта й, одночасно, об‘єкта освітнього процесу та на його центральну мету - на особистість дитини. Саме цього вимагає людиноцентрична парадигма освіти, 
розроблена В. Г. Кременем [5], в якій закладена загальна канва для визначення базових критеріїв ефективності освітянського процесу. Таким інтегральним критерієм, якщо виходити з всебічного розвитку особистості як головної мети освітньої діяльності, може бути розвивальний потенціал освітнього процесу у З3СО.

Ми пропонуємо виокремити серед найбільш загальних аспектів, які визначають рівень розвитку розвивального потенціалу освітніх послуг такі, як орієнтація освітнього процесу на розвиток суб'єктності учнів, на педагогіку співробітництва і співпрацю між учителем і учнем, спрямованість змісту навчальних послуг на інноваційне творче навчання, виховання в учнів креативних особистісних рис і творчого мислення, готовність педагога до інноваційної педагогічної діяльності.

Аналіз останніх досліджень і публікацій. Розглянемо докладніше систему навичок, дій, особистісних і розумових якостей учня, які надають можливість успішно засвоювати необхідні шкільні знання і вміння, й можуть розглядатися як показники і прояви розвиваючої дії освітнього процесу на особистість учня.

Такий комплекс різних навчально-пізнавальних навичок і способів дій школярів, які забезпечують здатність самостійно засвоювати нові вміння та знання, отримав в психолого-педагогічній літературі назву універсальних навчальних дій. Універсальні навчальні дї (УНД) - базовий елемент вміння вчитися; сукупність способів дій учня і навичок навчальної роботи, що забезпечують можливість самостійно розвиватися i вдосконалюватися в напрямку бажаного соціального досвіду протягом усього життя. Це узагальнені дії, що відкривають можливість широкої орієнтації учнів, - як в різних предметних областях, так і в будові самої навчальної діяльності, включаючи усвідомлення учнями її цільової спрямованості, ціннісно-смислових і операціональних характеристик $[4 ; 11 ; 12 ; 13 ; 14]$.

Теоретико-методологічною основою поняття є діяльнісний підхід, який базується на положеннях наукової школи О. Н. Леонтьєва [6], Д. Б. Ельконіна [10], П. Я. Гальперіна [2], В. В. Давидова [3], В. В. Репкіна [9], С. Д. Максименка [7]. В даному підході найбільш повно розкрито основні психолого-педагогічні умови і механізми процесу засвоєння знань, формування картини світу, а також загальна структура навчальної діяльності учнів, де УНД є одним з ключових понять в теорії розвиваючого навчання Д. Б. Ельконіна і В. В. Давидова. 
Метою статті $є$ аналіз теоретичних і практичних передумов моніторингу такого інтегрального показника якості освітніх послуг, як розвивальний потенціал освітнього процесу, та обгрунтування змісту і структури моніторингової методики вимірювання цього важливого аспекту освітянської діяльності у З3СО. До першочергових завдань дослідження належать: 1) вироблення системи об'єктивних критеріїв оцінювання й моніторингу розвивального потенціалу освітнього процесу; 2) подальша конкретизація принципів та інструментів моніторингу цього явища у вигляді експертної методики.

Теоретичні основи дослідження. УНД в освітньому процесі школи виступають в якості особистісних і метапредметних результатів освоєння учнями основної освітньої програми відповідного рівня загальної освіти (початкової, основної, середньої). Існують певні відмінності формування УНД в початкових класах, в середній ланці і старшій школі, пов'язані з віковими особливостями учнів, зміною цільових орієнтирів і характеру навчальної діяльності, перенесенням пріоритетів.

Зазначимо, що одною з найбільш важливих і неодмінних умов формування УНД на всіх щаблях освіти є забезпечення наступності в освоєнні учнями універсальних навчальних дій. Провідну роль у формуванні УНД також грає підбір змісту, розробка конкретного набору найбільш ефективних, яскравих і цікавих для учнів навчальних завдань.

До функцій універсальних навчальних дій відносяться: 1) забезпечення можливостей учня самостійно здійснювати таку дію як навчання, ставити перед собою навчальні цілі, шукати і використовувати необхідні засоби і способи їх досягнення, контролювати й оцінювати процес і результати діяльності; 2) створення умов для гармонійного розвитку особистості і іï самореалізації на основі готовності до безперервної освіти, необхідність якої обумовлена полікультурністю суспільства і високою професійною мобільністю; 3) забезпечення успішного засвоєння знань, умінь і навичок і формування компетентностей в будь-якій предметній області.

Тож оволодіння учнями універсальними навчальними діями відбувається в контексті різних навчальних предметів і, врешті-решт, веде до формування здатності самостійно успішно засвоювати нові знання, вміння і компетентності, включаючи самостійну організацію процесу засвоєння, тобто вміння вчитися. 
Методи дослідження. У процесі дослідження використовувались теоретичні методи: вивчення, аналіз, систематизація та узагальнення наукової і методичної літератури, в якій висвітлений комплекс зазначених освітньо-наукових проблем; застосовувався метод системного аналізу $і$ моніторингу інтегрального показника ефективності освітньої діяльності: розвивального потенціалу освітніх послуг; вивчалися специфічні типологічні прояви розвивального потенціалу та УНД як його складових тощо.

Результати дослідження. Аналіз літератури з питання, самостійні дослідження дозволили виділити наступні види універсальних навчальних дій: 1) nізнавальні, які мають такі різновиди: загальні навчальні діï (вміння поставити навчальну задачу, вибрати способи і знайти інформацію для iї вирішення, вміти працювати 3 інформацією, структурувати отримані знання); логічні навчальні діï (вміння аналізувати і синтезувати нові знання, встановлювати причинно-наслідкові зв'язки, доводити свої судження; вибудовування логічного плану дій; постановка гіпотези, іiі обгрунтування; доведення. Логічні навчальні дії сприяють створенню школярами самостійних варіантів вирішення різних завдань пошукового та творчого виду); постановка $i$ вирішення проблеми (вміння сформулювати проблему і знайти спосіб ㄲï вирішення); знаковосимволічні діï (моделювання і перетворення моделі). До них відносяться: моделювання; символічні дії; зміна моделі для виявлення загальних закономірностей, що стосуються певної предметної області.

2) Комунікативні - забезпечують соціальну компетентність та усвідомлену орієнтацію на позицію інших людей, перш за все партнера по спілкуванню або навчанню, та вміння слухати й вступати у діалог, брати участь у колективному обговоренні проблем, інтегруватися в групу однолітків, настроїти продуктивну взаємодію і співробітництво із однокласниками і вчителями.

3) Регулятивні - цілепокладання, планування, коригування плану; контроль у формі порівняння способу дії и його результата; оцінка, вольова саморегуляція. 4) Особистісні - забезпечують ціннісно-смислове орієнтацію учнів (вміння співвідносити вчинки і події з прийнятими етичними принципами, знання моральних норм і вміння виділити моральний аспект поведінки), а також орієнтацію в соціальних ролях і міжособистісних відносинах [4]. 
Систематизуємо основні прояви кожної із УНД у табл. 1. А також зведемо все сказане вище стосовно розвивального потенціалу освітніх послуг у табл. 2 «Критерії оцінювання розвивального потенціалу освітніх послуг», в якій розкриємо зміст кожного з рівнів розвитку універсальних навчальних дій.

Отже, розробивши критерії оцінювання розвивального потенціалу освітніх послуг, представлені у табл. 2, ми отримали методичний інструментарій для моніторингу такого інтегрального показника якості освітнього процесу у школі, як розвивальний потенціал освітніх послуг.

Крім того, на основі наведених у табл. 2 структури, змісту і критеріїв рівнів розвитку УНД визначаються рівні розвитку розвивального потенціалу освітніх послуг: високий, середній та низький, який підраховується на підставі розподілу загальної суми балів по рівнях розвитку УНД. Ці експертні дії відбуваються за допомогою розробленої нами авторської методики «Експертна карта оцінювання розвивального потенціалу освітніх послуг» представлена на таблиці 3. Зауважимо, що «Експертна карта» створена на основі скороченого, стислого варіанту табл. 2.

Табличя 1

Універсальні навчальні дії (УДД)

\begin{tabular}{|c|c|}
\hline Особистісні УНД & Комунікативні УНД \\
\hline $\begin{array}{lll}\text { Самовизначення } & \text { (мотивація } & \text { учіння, } \\
\text { формування } & \text { основ } & \text { громадянської }\end{array}$ & $\begin{array}{l}\text { Планування (визначення цілі, функцій } \\
\text { учасників, способів взаємодії). }\end{array}$ \\
\hline $\begin{array}{l}\text { iдентичності особистості). } \\
\text { Смислотворення («яке значення, зміст }\end{array}$ & $\begin{array}{l}\text { Постановка питань (ініціативна } \\
\text { співпраця у пошуці і зборі інформації). }\end{array}$ \\
\hline $\begin{array}{l}\text { має для мене учіння», і вміти знаходити } \\
\text { відповіді на це питання). } \\
\text { Морально-етичне оцінювання }\end{array}$ & $\begin{array}{l}\text { Вирішення конфліктів } \\
\text { iдентифікація проблеми, пошук і оцінка } \\
\text { альтернативних }\end{array}$ \\
\hline $\begin{array}{l}\text { (оцінювання засвоєного змісту,виходячи } 3 \\
\text { соціальних та особистісних цінностей, які }\end{array}$ & $\begin{array}{l}\text { конфлікта, прийняття рішення і його } \\
\text { реалізація). }\end{array}$ \\
\hline $\begin{array}{l}\text { забезпечують особистісний моральний } \\
\text { вибір). }\end{array}$ & $\begin{array}{l}\text { Управління поведінкою партнера } \\
\text { (контроль, корекція, оцінка дій партнера, } \\
\text { уміння } 3 \text { достатньою повнотою і точністю } \\
\text { виражати свої думки). }\end{array}$ \\
\hline Пізнавальні УНД & Регулятивні УНД \\
\hline $\begin{array}{l}\text { Загальнонавчальні } \\
\text { - формування пізнавальної цілі; } \\
\text { - пошук і виділення інформації; } \\
\text { - знаково-символічні; } \\
\text { - моделювання; } \\
\text { Логічні }\end{array}$ & $\begin{array}{l}\text { Цілепокладання (постановка навчальної } \\
\text { задачі на основі співвіднесення того, що } \\
\text { вже відомо і засвоєно учнями, і того, що } \\
\text { ще невідомо). } \\
\text { Планування (визначення послідовності } \\
\text { проміжних цілей з врахуванням кінцевого }\end{array}$ \\
\hline
\end{tabular}


- аналіз з цілью виділення ознак (істотних, неістотних);

- синтез як складання цілого 3 частин, заповнюючи відсутні компоненти;

- вибір підстав i критеріїв для порівнювання, серіації, класифікації об'єктів ;

- підведення під поняття ,виведення наслідків;

- встановлення причинно-наслідкових зв'язків;

- побудова логічного ланцюга роздумів;

- доказ;

- висування гіпотез та їх обгрунтування.

Дії з постановки і вирішення проблем:

- формулювання проблеми;

- самостійне створення способів вирішення проблем творчого та пошукового характеру .

результату;

складання плану і послідовності дій).

Прогнозування (передбачення результатів рівня засвоєння, його тимчасових характеристик).

Контроль (у формі звірення способу дій і його результату 3 заданим еталоном 3 метою виявлення відхилень і відмінностей від еталону).

Корекція (внесення необхідних доповнень і коректив до плану і способу діï у випадку розходження еталону, реальної дії і її продукту).

Оцінка (виділення і усвідомлення учнями того, що вже засвоєно і що ще підлягає засвоєнню,усвідомлення якості та рівня засвоєння).

Вольова саморегуляція (здатність до мобілізації сил та енергії; здатність до вольового зусилля - до вибору в ситуації мотиваційного конфлікту і до подолання перешкод).

За допомогою цього інструменту вимірювання ми проаналізували 85 33СО 3 метою встановити, який рівень розвивального потенціалу освітніх послуг вони мають, i отримали наступний розподіл: 1) низький інтегральний показник розвивального потенціалу освітніх послуг - 19 \%; 2) середній інтегральний

Таблицяя 2

\section{Критерії оцінювання розвивального потенціалу освітніх послуг}

\begin{tabular}{|c|c|c|c|c|}
\hline $\begin{array}{l}\text { Види } \\
\text { УНД } \\
\text { Рівні } \\
\text { прояву } \\
\text { УНД }\end{array}$ & Пізнавальні УНД & $\begin{array}{c}\text { Комунікативні } \\
\text { УНД }\end{array}$ & $\begin{array}{c}\text { Регулятивні } \\
\text { УНД }\end{array}$ & $\begin{array}{c}\text { Особистісн } \\
\text { і УНД }\end{array}$ \\
\hline $\begin{array}{l}\text { Високий } \\
\text { Індекс } 3\end{array}$ & $\begin{array}{lr}\text { Поряд із } \\
\text { лінійним } \\
\text { мисленням } \\
\text { нелінійне } \\
\text { мислененнян } \\
\text { вреативне } \\
\text { відтворення } \\
\text { варіювання } \\
\text { виражена здатність до } \\
\text { перебудови } \\
\text { яскраво } \\
\text { знань, до }\end{array}$ & $\begin{array}{l}\text { Діалогічність, } \\
\text { творча } \\
\text { атмосфера, } \\
\text { колективі } \\
\text { організована } \\
\text { розподілена } \\
\text { творча } \\
\text { діяльність; } \\
\text { вміння слухати }\end{array}$ & $\begin{array}{l}\text { Висока } \\
\text { самостійність і } \\
\text { відповідальне } \\
\text { відношення до } \\
\text { дорученої } \\
\text { справи, не } \\
\text { потребує опіки, } \\
\text { «підштовхуван } \\
\text { ня», }\end{array}$ & $\begin{array}{l}\text { Висока } \\
\text { пізнавальна } \\
\text { активність } \\
\text { учня і } \\
\text { пізнавальна } \\
\text { ініціатива } \\
\text { («ініціативн } \\
\text { ий рівень») }\end{array}$ \\
\hline
\end{tabular}




\begin{tabular}{|c|c|c|c|c|}
\hline & $\begin{array}{l}\text { комбінування, } \\
\text { реконструювання, } \\
\text { аналогізування, } \\
\text { зближення віддалених } \\
\text { ідей тощо. Вміння } \\
\text { самостійно поставити } \\
\text { навчальну задачу, } \\
\text { вибрати способи і } \\
\text { знайти інформацію } \\
\text { для її вирішення }\end{array}$ & $\begin{array}{l}\text { й вступати у у } \\
\text { діалог, брати } \\
\text { участь } \\
\text { колективному } \\
\text { обговоренні } \\
\text { проблем, } \\
\text { інтегруватися в } \\
\text { групу } \\
\text { однолітків, } \\
\text { настроїти } \\
\text { продуктивну } \\
\text { взаємодію } \\
\text { співробітництво } \\
\text { із } \\
\text { однокласниками } \\
\text { і вчителями; } \\
\text { комунікація } \\
\text { «учень-вчитель» } \\
\text { горизонтальна }\end{array}$ & $\begin{array}{l}\text { «підстьобування», } \\
\text { висока } \\
\text { цілеспрямовані } \\
\text { сть; автономна } \\
\text { стадія } \\
\text { моральної } \\
\text { поведінки }\end{array}$ & \\
\hline $\begin{array}{l}\text { Середній } \\
\text { Індекс } 2\end{array}$ & 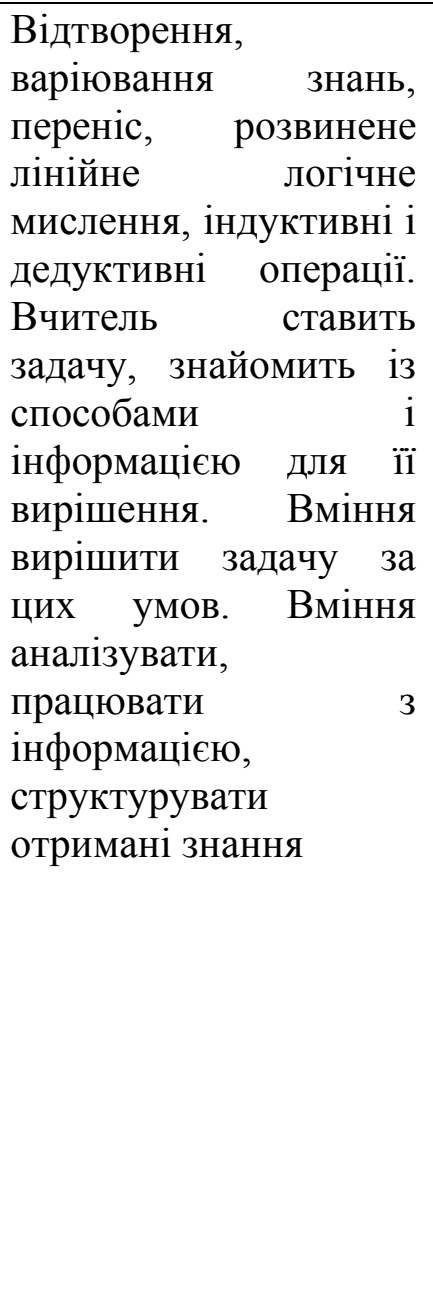 & $\begin{array}{l}\text { Вчитель } \\
\text { домінує, але } \\
\text { заохочує учня } \\
\text { до співробітниц- } \\
\text { тва і діалогу, } \\
\text { поступово } \\
\text { послаблюючи } \\
\text { домінування по } \\
\text { мірі розвитку } \\
\text { суб'єктності } \\
\text { учня; } \\
\text { комунікація } \\
\text { «учень-вчитель» } \\
\text { вертикально- } \\
\text { горизонтальна; } \\
\text { вміння слухати } \\
\text { й вступати у } \\
\text { діалог, брати } \\
\text { участь у } \\
\text { колективному } \\
\text { обговоренні } \\
\text { проблем, } \\
\text { інтегруватися в } \\
\text { групу } \\
\text { однолітків, } \\
\text { настроїти } \\
\text { продуктивну }\end{array}$ & $\begin{array}{l}\text { Самостійність } \\
\text { знижена, учень } \\
\text { звертається } \\
\text { допомогою } \\
\text { педагога } \\
\text { батьків, чекає } \\
\text { вказівок } \\
\text { дорослих, яід } \\
\text { старанно } \\
\text { виконує; } \\
\text { цілепокладання } \\
\text { потребує } \\
\text { опікування } \\
\text { боку дорослих; } \\
\text { конвенційна } \\
\text { стадія } \\
\text { моральної } \\
\text { поведінки }\end{array}$ & $\begin{array}{l}\text { Виконавськ } \\
\text { ість, } \\
\text { старанність } \\
\text {, завдання } \\
\text { виконуютьс } \\
\text { я «від» і } \\
\text { «до», але } \\
\text { без } \\
\text { ініціативи } \\
\text { («виконавс } \\
\text { ький } \\
\text { рівень») }\end{array}$ \\
\hline
\end{tabular}




\begin{tabular}{|c|c|c|c|c|}
\hline & & $\begin{array}{l}\text { взаємодію і } \\
\text { співробітництво } \\
\text { iз } \\
\text { однокласниками } \\
\text { і вчителями } \\
\text { тощо }\end{array}$ & & \\
\hline $\begin{array}{l}\text { Низький } \\
\text { Індекс } 1\end{array}$ & $\begin{array}{lr}\text { Часткове } & \text { відтворення } \\
\text { за зразком, слабке } \\
\text { логічне } \\
\text { слабкі мислення, } \\
\text { індукції і } \\
\text { аналізу дедукції, } \\
\text { Невміння впоратися із } \\
\text { задачею. }\end{array}$ & 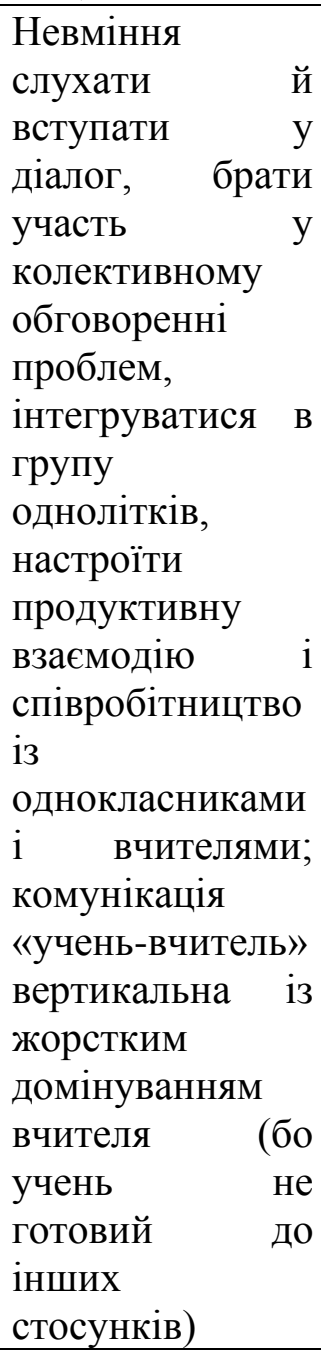 & $\begin{array}{l}\text { Відсутності } \\
\text { здатності } \\
\text { вирішувати } \\
\text { проблему без } \\
\text { відповідних } \\
\text { вказівок, учень } \\
\text { потребує } \\
\text { жорсткого } \\
\text { контролю і } \\
\text { «підштовхуван } \\
\text { ня»; проявляє } \\
\text { негативізм у у } \\
\text { поведінці; цілі } \\
\text { ставить лише } \\
\text { ситуативні; } \\
\text { доморальна } \\
\text { (інструменталь } \\
\text { на) стадія } \\
\text { моральної } \\
\text { поведінки }\end{array}$ & $\begin{array}{l}\text { Пасивність } \\
\text { в учбовому } \\
\text { процесі, що } \\
\text { доходить } \\
\text { до повної } \\
\text { байдужості, } \\
\text { ніякого } \\
\text { інтересу до } \\
\text { знань, } \\
\text { відсутність } \\
\text { старанності } \\
\text { в ході } \\
\text { виконання } \\
\text { («пасивний } \\
\text { рівень») }\end{array}$ \\
\hline $\begin{array}{l}\text { Інтеграль } \\
\text { ний } \\
\text { показник } \\
\text { розвиваль } \\
\text { ного } \\
\text { потенціалу } \\
\text { освітніх } \\
\text { послуг } \\
\text { А+B+C+D= }\end{array}$ & A & B & $\mathrm{C}$ & $\mathrm{D}$ \\
\hline
\end{tabular}


Експертна карта оцінювання розвивального потенціалу освітніх послуг 33СО

З3СО №__ місто (село, смт)

\begin{tabular}{|c|c|c|c|c|}
\hline $\begin{array}{l}\text { Види } \\
\text { УНД } \\
\text { Рівні } \\
\text { прояву } \\
\text { УНД }\end{array}$ & $\begin{array}{c}\text { Пізнавальні } \\
\text { УНД } \\
\text { А }\end{array}$ & $\begin{array}{c}\text { Комунікативн } \\
\text { і УНД } \\
\text { В }\end{array}$ & $\begin{array}{c}\text { Регулятивні } \\
\text { УНД } \\
\text { С }\end{array}$ & $\begin{array}{c}\text { Особисті } \\
\text { сні УНД } \\
\text { D }\end{array}$ \\
\hline $\begin{array}{c}\text { Високий } \\
\text { iндекс = } 3\end{array}$ & & & & \\
\hline $\begin{array}{l}\text { Середній } \\
\text { індекс = } 2\end{array}$ & & & & \\
\hline $\begin{array}{c}\text { Низький } \\
\text { індекс = } 1\end{array}$ & & & & \\
\hline $\begin{array}{c}\text { Інтегральний } \\
\text { показник } \\
\text { розвивального } \\
\text { потенціалу освітніх } \\
\text { послуг } \mathrm{A}+\mathrm{B}+\mathrm{C}+\mathrm{D}=\end{array}$ & $\begin{array}{c}\text { Високий } \\
\text { інтегральний } \\
\text { показник, } \\
\text { діапазон балів } \\
\text { 10-12 }\end{array}$ & $\begin{array}{c}\text { Середній } \\
\text { інтегральний } \\
\text { показник, } \\
\text { діапазон балів } \\
\text { 7-9 }\end{array}$ & $\begin{array}{c}\text { Низький } \\
\text { інтегральний } \\
\text { показник, } \\
\text { діапазон балів } \\
\text { 4-6 }\end{array}$ & \\
\hline
\end{tabular}

показник розвивального потенціалу освітніх послуг - $63 \%$; 3) високий інтегральний показник розвивального потенціалу освітніх послуг - $18 \%$.

Як бачимо, найбільш вагомо представленим виявилися навчальні заклади із середнім інтегральним показником.

Висновки та перспективи подальших досліджень. Отже, питома вага 33СО із конструктивним розвивальним потенціалом освіти, куди входять середній і високий рівні, виявилася абсолютно переважаючою - 81 \%. Але, не дивлячись на цей, в цілому позитивний показник, існують великі резерви для покращення якості освітніх послуг у напрямку підвищення ваги З3СО із високим розвивальним потенціалом за рахунок підсилення в змісті освітнього процесу творчих компонентів. Також необхідно використати ті фактори, які дозволять підвищити якість навчального процесу й суттєво зменшити серед них долю $33 \mathrm{CO}$ із низьким інтегральним показником розвивального потенціалу.

Разом із тим, серед перспектив наших подальших досліджень стоїть завдання дослідити і систематизувати фактори покращення якості освітніх послуг. 


\section{References}

1. Bobrovskyi M. V., Horbachov S. I., Zaplotynska O. O. Rekomendatsii do pobudovy vnutrishnoi systemy zabezpechennia yakosti osvity u zakladi zahalnoi serednoi osvity [Recommendations for building an internal system for ensuring the quality of education in general secondary education]. Kyiv : Derzhavna sluzhba yakosti osvity, 2019. 240 p.

2. Halperyn P. Ya. Metody obuchenyia $i$ umstvennoe razvitie rebenka [Teaching methods and mental development of the child]. Moskva, 1985.

3. Davydov V.V. Teoryia razvivaiushcheho obuchenia [Developmental learning theory]. Moskva, 1996.

4. Kak proektyrovat unyversalnye uchebnye deistvyia $v$ nachalnoi shkole: ot deistvyia $k$ mysli [How to Design Universal Learning Activities in Primary School: From Action to Thought] : posobye dlia uchitelia / [A. H. Asmolov i dr.]. Moskva : Prosveshchenie, 2008. $172 \mathrm{p}$.

5. Kremen V.H. Osobystisno-rozvyvalne navchannia yak naukovyi priorytet [Personality and developmental learning as a scientific priority]. Ridna shkola. 1998. No. 11. Pp. 25-28.

6. Leontev A. N. Lektii po obshchei psykholohii [General Psychology Lectures]. Moskwa, 2001.

7. Maksymenko S. D. Psykholohiia $v$ sotsialnii ta pedahohichnii praktytsi. Metodolohiia. Metody. Prohramy. Protsedury [Psychology in social and pedagogical practice]. Kyiv : Naukova dumka. 1999.

8. Moliako V.A. Psykholohyia reshenyia shkolnykamy tvorcheskykh zadach [Psychology of solving creative problems by schoolchildren]. Kyiv : Radianska shkola. 1983. $94 \mathrm{p}$.

9. Repkyn V. V., Repkyna N. V. Razvyvaiushchee obuchenye: teoryia i praktika [Developmental education: theory and practice]. Tomsk, 1997.

10. El'konin D. B. Psikhologiya razvitiya [Psychology of development] : ucheb. posobiye dlya stud. vyssh. ucheb. zavedeniy. Moskwa, 2001.

11. Didur N., Matviienko O. The modern condition of forming sociocultural competence in future elementary school teachers. Intellectual Archive. - Toronto : Shiny Word. Corp. (Canada), 2017. Vol. 6. No. 6. Pp. 103-112.

12. Pet'ko L.V. Development of students' cognitive activity in foreign language teaching by using analogy method // Actual problems of globalization: Collection of scientific articles. - Midas S.A., Thessaloniki, Greece, 2016. P. 232-237.

13. Pet'ko L. Priorities for the development of the Ukrainian national idea and the upbringing students of this modern era. Intellectual Archive. Toronto: Shiny Word.Corp. (Canada), 2017. Vol. 6. No. 5, September/October. Pp. 59-78.

14. Ternopilska V. I., Brovko K. A. Corporate culture of personality:

psychological aspects. Topical issues of contemporary science: Collection of scientific articles. C.E.I.M., Valencia, Venezuela, 2017. Pp. 176-178. 


\section{Translation of the Title, Abstract and References to the Author's Language}

УДК 37.017

\section{Анотація}

Зварич Ганна. Моніторинг розвивального потенціалу освітніх послуг у закладах загальної середньої освіти.

Представлено результати наукових досліджень з проблеми моніторингу якості освітніх послуг. Проаналізовано й узагальнено важливі параметри такого моніторингу. Проаналізовано питання стосовно вимірювання якості освітніх послуг в освітньому закладі. Запропоновано розроблені інтегральні показники якості освітніх послуг, які б об'єднували багато факторів освітньої діяльності та відбивали центральну мету освітнього процесу - розвиток особистості дитини. Висвітлено систему навичок, умінь, особистісних і розумових якостей учня, які надають можливість успішно засвоювати необхідні шкільні знання і вміння, і розглядаються як показники прояву ефективної розвиваючої дії освітнього процесу на особистість учня, що характеризують розвивальний потенціал освітніх послуг.. Виокремлено види універсальних навчальних дій: пізнавальні (вміння вчитися, логічно мислити тощо), комунікативні (соціальна компетентність, вміння спілкуватися і таке інше), регулятивні (цілепокладання, планування тощо), особистісні (забезпечують ціннісно-смислові й морально-етичні орієнтації учнів). Розроблено критерії і рівні оцінювання розвивального потенціалу освітніх послуг. Отримано методичний інструментарій для моніторингу цього інтегрального показника.

Ключові слова: моніторинг якості освітніх послуг, розвивальний потенціал, універсальні навчальні дії, пізнавальні дії, регулятивна діяльність.

\section{Лumepamypa}

1. Бобровський М. В., Горбачов С. І., Заплотинська О. О. Рекомендації до побудови внутрішньої системи забезпечення якості освіти у закладі загальної середньої освіти. Київ : Державна служба якості освіти, 2019. 240 с.

2. Гальперин П. Я. Методы обучения и умственное развитие ребенка. Москва, 1985.

3. Давыдов В. В. Теория развивающего обучения. Москва, 1996.

4. Как проектировать универсальные учебные действия в начальной школе: от действия к мысли: пособие для учителя / [А. Г. Асмолов и др.]. Москва : Просвещение, 2008. $172 \mathrm{c}$.

5. Кремень В. Г. Особистісно-розвивальне навчання як науковий пріоритет. Рідна школа. 1998. № 11. С. 25-28.

6. Леонтьев А. Н. Лекции по общей психологии. Москва, 2001.

7. Максименко С. Д. Психологія в соціальній та педагогічній практиці. Методологія. Методи. Програми. Процедури. Київ : Наукова думка. 1999.

8. Моляко В.А. Психология решения школьниками творческих задач. Київ : Радянська школа, 1983. 94 с. 
9. Репкин В. В., Репкина Н. В. Развивающее обучение: теория и практика. Томск, 1997.

10. Эльконин Д. Б. Психология развития : учеб. пособие для студ. высш. учеб. заведений. Москва, 2001.

11. Didur N., Matviienko O. The modern condition of forming sociocultural competence in future elementary school teachers. Intellectual Archive. Toronto : Shiny Word. Corp. (Canada), 2017. Vol. 6. No. 6. Pp. 103-112.

12. Pet'ko L. V. Development of students' cognitive activity in foreign language teaching by using analogy method // Actual problems of globalization: Collection of scientific articles. - Midas S.A., Thessaloniki, Greece, 2016. P. 232-237.

13. Pet'ko L. Priorities for the development of the Ukrainian national idea and the upbringing students of this modern era. Intellectual Archive. Toronto : Shiny Word.Corp. (Canada), 2017. Vol. 6. No. 5, September/October. Pp. 59-78.

14. Ternopilska V. I., Brovko K. A. Corporate culture of personality: psychological aspects. Topical issues of contemporary science: Collection of scientific articles. C.E.I.M., Valencia, Venezuela, 2017. Pp. 176-178. 